\title{
Investigation of the Impact of SARS-CoV-1 Infection on the Immunologic Status and Lung Function After 15 Years
}

Jia Li

Peking University People's Hospital

\section{Yali Zheng}

Peking University People's Hospital

\section{Lili Zhao}

Peking University People's Hospital

\section{Zhihong Yue}

Peking University People's Hospital

\section{Feng Pan}

Peking University People's Hospital

\section{Yuehong Chen}

Academy of Military Medical Sciences

\section{Bing Yu}

Peking University People's Hospital

\section{Yanwen Chen}

Peking University People's Hospital

\section{Guangyu Zhao}

Academy of Military Medical Sciences

\section{Yusen Zhou}

Academy of Military Medical Sciences

Zhancheng Gao ( $\nabla$ zcgao@bjmu.edu.cn )

Peking University People's Hospital

\section{Research Article}

Keywords: Severe acute respiratory syndrome (SARS), SARS-CoV specific IgG antibody, Regulatory T cell, HRCT, pulmonary function test

Posted Date: May 12th, 2021

DOI: https://doi.org/10.21203/rs.3.rs-386485/v1 
License: (c) (i) This work is licensed under a Creative Commons Attribution 4.0 International License. Read Full License

Version of Record: A version of this preprint was published at BMC Infectious Diseases on November 24th, 2021. See the published version at https://doi.org/10.1186/s12879-021-06881-3. 


\section{Abstract}

Background: To investigate the long-term effects of SARS-CoV-1 on patients' lung and immune systems 15 years post-infection.

Methods: We enrolled 58 health care workers with confirmed SARS in Peking University People's Hospital in 2003. We evaluated lung damage by mMRC score, pulmonary function tests, and chest CT. Immune function was assessed by their serum levels of globin, complete components, and peripheral T cell subsets. ELISA was used to detect SARS-CoV-specific IgG antibodies in sera.

Results: After 15 years of disease onset, 19 (36.5\%), 8 (34.6\%), and 19 (36.5\%) subjects had impaired $\mathrm{DL}(\mathrm{CO}), \mathrm{RV}$, and $\mathrm{FEF}_{25-75}$, respectively. 17 (30.4\%) subjects had an mMRC score $\geq 2$. Fourteen (25.5\%) cases had residual CT abnormalities. T regulatory cells were a bit higher in the SARS survivors. IgG antibodies against SARS S-RBD protein and N protein were detected in 11 (18.97\%) and $12(20.69 \%)$ subjects, respectively. Subgroup analysis revealed that small airway dysfunction and CT abnormalities were more common in the severe group than in the non-severe group ( $57.1 \%$ vs $22.6 \%, 54.5 \%$ vs $6.1 \%$, respectively, $p<0.05)$.

Conclusions: SARS-CoV-1 could cause permanent damage to the lung, which requires early pulmonary rehabilitation. The long-lived immune memory response against coronavirus requires further studies to assess the potential benefit.

Trail registration: ClinicalTrials.gov, NCT03443102. Registered prospectively on 22/02/2018.

\section{Background}

Severe acute respiratory syndrome (SARS) caused by SARS-CoV occurred in China in late 2002 and subsequently spread over the world [1, 2]. Up to September 2003, more than 8000 laboratory-confirmed cases had been documented globally, of which about $30 \%$ were severe cases, and $20 \%$ were health care workers (HCWs) [3]. At the end of 2019, a new coronavirus (SARS-CoV-2) emerged and caused an outbreak of pneumonia (now called COVID-19). The novel coronavirus pneumonia has now spread fast all over the world [4] and has infected approximately $11 \%$ HCWs [5]. SARS-CoV- 1 and SARS-CoV-2 might cause similar pathological changes since they both invade the alveolar epithelial cells through the ACE-2 receptors [6]. Therefore, we assumed that the long-term effects of SARS-CoV-1 could provide some insight into the impact of COVID-19 on long-term conditions [7]. We investigated the current status of the immune system and lung 15 years after SARS-CoV-1 infection in the current study. Subgroup analyses were conducted to explore the differences between the severe group and the non-severe groups, according to previous severity of illness.

\section{Methods}

\section{Study design and participants}


Fifty-eight HCWs with confirmed SARS-CoV infection in Peking University People's Hospital in the 2003 pandemic were enrolled in the study. Diagnose criteria were established by the Chinese Centers for Disease Control and Prevention. Fifty-seven of their co-workers, who also a history of SARS exposure in 2003, were enrolled as controls matched by gender, age, and occupational classifications.

The baseline characteristics and medical histories were collected by a standard questionnaire. The evaluation index system in the study includes the general status, the pulmonary status, and the immunity status. The general status was evaluated by regular laboratory tests including complete blood count (CBC) and blood biochemistry examination. Peripheral blood samples were collected from both SARS cases and controls on empty stomach in the early morning. The pulmonary status was assessed by the dyspnea scale (mMRC), the pulmonary function tests (PTFs), and the chest CT scans. The clinical immunologic evaluations of enrolled subjects included quantitation of serum immunoglobulins (IgA, IgG, and IgM) and complement components (C3 and C4), the WBC count, and differential counts of T lymphocyte subsets. Besides, we conducted serologic tests to see whether there are still detectable IgG antibodies against SARS-CoV after 15 years. The flowchart is shown in Fig. 1. Specific steps for the process are as follows.

\section{SARS-CoV IgG Antibody Test}

Enzyme-linked immunosorbent assay (ELISA) was performed to detect the IgG antibodies against SARS$\mathrm{CoV}$ in serum. For IgG detection, ELISA plates were coated with purified recombinant SARS protein antigens (S-RBD protein or N protein). Serum samples (diluted 1:160) and negative and positive controls were added to the wells of the coated plates in a total volume of $100 \mu \mathrm{l}$, plates were then incubated at $37^{\circ} \mathrm{C}$ for $30 \mathrm{~min}$. After five wash steps with washing buffer, $100 \mu$ of diluted HRP-conjugated anti-human IgG antibodies was added to the wells, and samples were incubated at $37^{\circ} \mathrm{C}$ for $30 \mathrm{~min}$. After five wash steps with washing buffer, $50 \mu \mathrm{l}$ of TMB substrate solution and $50 \mu \mathrm{l}$ of the corresponding buffer were added, and samples were incubated at $37^{\circ} \mathrm{C}$ for $10 \mathrm{~min}$. The reaction was terminated by adding $50 \mu \mathrm{l}$ of 2 $M$ sulfuric acid, and A450 was measured.

Sixteen serum samples from a pneumonia cohort (NCT 03093220) were used as controls to rule out the nonspecific cross-immunoreactivity. Absorbance at $450 \mathrm{~nm}$ was measured by ELISA Microplate Reader. The cut-off OD value was calculated as 1.5 times the normal threshold of the controls.

\section{Lung imaging and interpretation}

A total of 55 patients underwent lung high-resolution CT (HRCT) examination in March 2018. HRCT was performed by the GE 256-row Revolution scanner with inspiratory and expiratory phases, respectively. The radiological images were reviewed independently by two radiologists and final interpretation was established by consensus, including the following HRCT abnormalities: ground-glass opacity, consolidation, fibrous strip shadow, emphysema, pulmonary bullae, bronchiectasis, and pleural thickening.

\section{Pulmonary function tests (PFTs)}


Dyspnea in daily living was evaluated by the mMRC scale. Pulmonary function tests (PFTs) included spirometry, plethysmography, diffusing capacity of carbon monoxide were conducted. The main observation indicators included total lung capacity (TLC), residual volume (RV), forced vital capacity $(F V C)$, forced expiratory volume in one second $\left(F V_{1}\right)$, one-second rate $\left(F V_{1} / F V C\right)$, maximum midexpiratory flow rate $25-75\left(\mathrm{FEF}_{25}-75\right)$, and carbon monoxide diffusion amount (DL(CO)) measured by a single breath test. Values below $80 \%$ prediction were regarded as being impaired. RV over $120 \%$ predicted and $\mathrm{FEF}_{25-75}$ below $65 \%$ predicted as being damaged.

\section{Statistical analysis}

All the analyses were performed with the SPSS software, version 22.0, (IBM Corp., Armonk, NY, USA) unless otherwise indicated. Continuous variables were expressed as medians (interquartile ranges) or mean $\pm S D$ and compared by Student's t-test or Mann-Whitney $U$ tests for normal or non-normal distribution, respectively. Categorical variables were expressed as numbers (proportion). P-values $<0.05$ were considered significant.

\section{Ethical approval}

The study was approved by the ethics committee of Beijing University People's Hospital (PHB010201801) and was registered on the Clinical trials website (https://clinicaltrials.gov/) (NCT03443102). The written informed consent was obtained from all participants.

\section{Results}

\section{Demographic and clinical features}

As shown in Table 1, among the $58 \mathrm{HCWs}$ enrolled in the study, ten were male (17.2\%), and the median age was 46 years (IQR 40.0-50.5) up to 2018. The majority of them were nurses who worked in the Emergency Department during the 2003 pandemic. Thirty-five patients were categorized as non-severe pneumonia in 2003, and 23 cases as severe pneumonia. Up to March 2018, most of them (47/58, 81.0\%) were still full-time employed. Sixteen of them had hypertension, five had diabetes, and one had Sjogren's syndrome. Nearly half of the subjects complained of fatigue $(27 / 58,46.55 \%)$. Thirty-nine $(39 / 56,69.6 \%)$ SARS survivors had an mMRC score of $0-1$ and 17 subjects $(17 / 56,30.4 \%)$ had $2-3$. (Table 2 ) 
Table 1

Demographic data of SARS survivors and controls

\begin{tabular}{|c|c|c|c|c|c|}
\hline & $\begin{array}{l}\text { The Severe } \\
\text { Group } \\
(\mathrm{N}=23)\end{array}$ & $\begin{array}{l}\text { The Non-Severe } \\
\text { Group } \\
(\mathrm{N}=35)\end{array}$ & $\begin{array}{l}\text { The Control } \\
\text { Group } \\
(\mathrm{N}=57)\end{array}$ & $\begin{array}{l}\mathrm{F} / \mathrm{T} \\
\text { value }\end{array}$ & $\begin{array}{l}\mathrm{P} \text { - } \\
\text { value }\end{array}$ \\
\hline \multicolumn{6}{|l|}{ Age of onset } \\
\hline$<30$ years & $6(26.1 \%)$ & 18 (51.4\%) & 28 (49.1\%) & 4.294 & 0.117 \\
\hline$\geq 30$ years & 17 (73.9\%) & 17 (48.6\%) & 29 (50.9\%) & & \\
\hline \multicolumn{6}{|l|}{ Gender } \\
\hline female & $19(82.6 \%)$ & 29 (82.9\%) & 46 (80.7\%) & 0.082 & 0.960 \\
\hline male & $4(17.4 \%)$ & $6(17.1 \%)$ & $11(19.3 \%)$ & & \\
\hline \multicolumn{6}{|l|}{ Occupations } \\
\hline Doctor & $3(13.0 \%)$ & $4(11.4 \%)$ & $16(28.1 \%)$ & 9.079 & 0.169 \\
\hline Nurse & $15(65.2 \%)$ & 25 (71.4\%) & $32(56.1 \%)$ & & \\
\hline Technician & $3(13.0 \%)$ & $6(17.1 \%)$ & $8(14.0 \%)$ & & \\
\hline Others & $2(8.7 \%)$ & 0 & $1(1.8 \%)$ & & \\
\hline \multicolumn{6}{|l|}{ Departments } \\
\hline $\begin{array}{l}\text { Emergency } \\
\text { room }\end{array}$ & $11(47.8 \%)$ & $12(39.3 \%)$ & $26(45.6 \%)$ & 4.871 & 0.771 \\
\hline Cardiology & $3(13.0 \%)$ & $3(8.6 \%)$ & $3(5.3 \%)$ & & \\
\hline Pulmonology & $2(8.7 \%)$ & $2(5.7 \%)$ & $7(12.3 \%)$ & & \\
\hline Surgery & $2(8.7 \%)$ & $3(8.6 \%)$ & $3(5.3 \%)$ & & \\
\hline Others & $5(21.7 \%)$ & 15 (42.9\%) & 18 (31.6\%) & & \\
\hline
\end{tabular}


Table 2

The lung status of SARS survivors assessed by mMRC score, pulmonary function tests, and chest CT.

\begin{tabular}{|c|c|c|c|c|}
\hline & The Severe Group & The Non-severe Group & $\mathrm{F} / \mathrm{T}$ & $\mathbf{P}$ \\
\hline mMRC score ${ }^{a}$ & $N=22$ & $N=34$ & & \\
\hline 0 & $5(22.7 \%)$ & $11(32.4 \%)$ & 4.785 & 0.310 \\
\hline 1 & $11(50.0 \%)$ & $12(35.3 \%)$ & & \\
\hline 2 & $3(13.6 \%)$ & $10(29.4 \%)$ & & \\
\hline 3 & $3(13.6 \%)$ & $1(2.9 \%)$ & & \\
\hline Pulmonary function parameters ${ }^{\mathrm{b}}$ & $N=21$ & $N=31$ & & \\
\hline $\mathrm{FVC}(\mathrm{L})$ & $3.10 \pm 0.59$ & $3.52 \pm 0.6$ & -2.517 & 0.015 \\
\hline FVC (\%) & $101.41 \pm 14.52$ & $104.69 \pm 13.30$ & 0.835 & 0.408 \\
\hline FVC $\%<80 \%$ & 0 & 0 & - & - \\
\hline FEV1(L) & $2.48 \pm 0.514$ & $2.90 \pm 0.453$ & 3.313 & 0.003 \\
\hline FEV1 (\%) & $95.21 \pm 12.46$ & $101.61 \pm 12.66$ & 1.604 & 0.108 \\
\hline FEV1 $\%<80 \%$ & $4(19.0 \%)$ & 0 & 6.397 & $0 \otimes 011$ \\
\hline FEV1/FVC (\%) & $79.23 \pm 4.35$ & $82.64 \pm 4.80$ & 2.611 & 0.012 \\
\hline $\mathrm{FEV} 1 / \mathrm{FVC}<70 \%$ & $1(4.8 \%)$ & 0 & 1.505 & 0.220 \\
\hline $\mathrm{DLCO}(\mathrm{mmol} / \mathrm{min} / \mathrm{KPa})$ & $6.86 \pm 1.31$ & $7.18 \pm 1.43$ & 0.807 & 0.424 \\
\hline DLCO (\%) & $84.01 \pm 11.06$ & $82.18 \pm 12.42$ & -0.563 & 0.576 \\
\hline DLCO $\%<80 \%$ & $6(28.6 \%)$ & $13(41.9 \%)$ & 0.964 & 0.326 \\
\hline $\operatorname{TLC}(\mathrm{L})$ & $5.05 \pm 0.87$ & $5.39 \pm 0.71$ & 1.599 & 0.116 \\
\hline TLC (\%) & $100.32 \pm 10.83$ & $103.93 \pm 9.37$ & 1.277 & 0.207 \\
\hline TLC\% $<80 \%$ & 0 & 0 & - & - \\
\hline RV/TLC (\%) & $38.69 \pm 5.86$ & $37.23 \pm 5.77$ & -0.889 & 0.378 \\
\hline $\mathrm{RV}(\%)$ & $107.73 \pm 13.66$ & $111.70 \pm 17.22$ & 0.884 & 0.381 \\
\hline $\mathrm{RV} \%>120 \%$ & $6(28.6 \%)$ & $12(38.7 \%)$ & 0.569 & 0.451 \\
\hline FEF25-75 (\%) & $65.95 \pm 19.73$ & $82.69 \pm 20.36$ & 2.946 & 0.005 \\
\hline FEF25-75 \% $<65 \%$ & $12(57.1 \%)$ & $7(22.6 \%)$ & 6.449 & 0.011 \\
\hline CT abnormalities ${ }^{c}$ & $N=22$ & $N=33$ & & \\
\hline
\end{tabular}




\begin{tabular}{|lllll|}
\hline & \multicolumn{1}{c}{ The Severe Group } & The Non-severe Group & F/T & P \\
\hline GGO & $6(27.3 \%)$ & $2(6.0 \%)$ & 16.360 & $<0.001$ \\
\hline interstitial fibrosis & $7(31.8 \%)$ & 0 & & \\
\hline Others & $5(22.7 \%)$ & $1(3.0 \%)$ & & \\
\hline a, b, c, The number of SARS survivors undertaking different tests. & & \\
\hline
\end{tabular}

\section{Immunological features 15 years after recovering from the SARS-CoV pneumonia}

The results of $\mathrm{CBC}$ and biochemical tests were within the normal range, as well as serum immunoglobulin tests. There was no statistically significant difference among the severe group, the nonsevere group, and the control group $(p>0.05)$. Complement $4\left(C_{4}\right)$ were a bit higher in the non-severe group, with values of $0.22 \pm 0.06,0.27 \pm 0.18$ and $0.22 \pm 0.06 \mathrm{~g} / \mathrm{L}$, respectively, $F=3.547, p=0.032$. (Table 3).

T cell subsets were all within normal limits. The percentage of peripheral $\mathrm{CD}_{4}{ }^{+} \mathrm{CD}_{25}{ }^{+} \mathrm{Foxp}_{3}{ }^{+}$regulatory $\mathrm{T}$ cells was slightly higher in the SARS survivors, as compared to the controls ( $3.85 \pm 1.31 \%$ vs $3.34 \pm 0.97 \%$, respectively, $\mathrm{T}=2.420, \mathrm{p}=0.018$ ). (Fig. 2).

The serum antibody test results of SARS survivors showed that SARS-CoV N protein IgG antibody and SRBD protein IgG antibody were positive in 11 (18.97\%) and 12 (20.69\%), respectively. (Fig. 3) 
Table 3

Laboratory evaluation of immune status of SARS survivors.

\begin{tabular}{|c|c|c|c|c|c|}
\hline & $\begin{array}{l}\text { The Severe } \\
\text { Group } \\
(\mathrm{N}=23)\end{array}$ & $\begin{array}{l}\text { The Non-Severe } \\
\text { Group } \\
(\mathrm{N}=35)\end{array}$ & $\begin{array}{l}\text { The Control } \\
\text { Group } \\
(\mathrm{N}=57)\end{array}$ & $\begin{array}{l}\mathrm{F} / \mathrm{T} \\
\text { value }\end{array}$ & $\begin{array}{l}\mathrm{P} \text { - } \\
\text { value }\end{array}$ \\
\hline $\lg A(G / L)$ & $2.20 \pm 0.97$ & $2.41 \pm 0.97$ & $2.21 \pm 0.73$ & 0.555 & 0.576 \\
\hline $\lg G(G / L)$ & $11.84 \pm 1.97$ & $12.80 \pm 2.32$ & $12.94 \pm 2.18$ & 2.985 & 0.055 \\
\hline $\lg M(G / L)$ & $0.98 \pm 0.40$ & $1.03 \pm 0.38$ & $1.09 \pm 0.45$ & 0.742 & 0.478 \\
\hline C3 (G/L) & $0.88 \pm 0.13$ & $0.98 \pm 0.18$ & $0.94 \pm 0.18$ & 2.928 & 0.058 \\
\hline C4 (G/L) & $0.22 \pm 0.06$ & $0.27 \pm 0.18$ & $0.22 \pm 0.06$ & 3.547 & 0.032 \\
\hline $\mathrm{CD} 4+(\%)$ & $50.69 \pm 13.21$ & $51.82 \pm 10.25$ & $51.20 \pm 10.10$ & 0.071 & 0.931 \\
\hline CD8+ (\%) & $40.82 \pm 10.97$ & $39.71 \pm 10.61$ & $38.48 \pm 9.75$ & 0.569 & 0.568 \\
\hline $\begin{array}{l}\text { CD4 + CD25+ } \\
\text { Foxp3+ (\%) }\end{array}$ & $3.84 \pm 1.43$ & $3.89 \pm 1.12$ & $3.34 \pm 0.97$ & 2.862 & 0.061 \\
\hline \multicolumn{6}{|c|}{$\begin{array}{l}\text { IgA, immunoglobulin A, normal value } 0.82-4.53 \mathrm{~g} / \mathrm{L} ; \mathrm{lgG} \text {, immunoglobulin } \mathrm{G} \text {, normal value } 7.2-16.8 \\
\mathrm{~g} / \mathrm{L} ; \text { IgM, immunoglobulin } \mathrm{M} \text {, normal value } 0.46-3.04 \mathrm{~g} / \mathrm{L} ; \mathrm{C} 3 \text {, complement3, normal value } 0.79-1.52 \\
\mathrm{~d} / \mathrm{L}, \mathrm{C4} \text {, complement4, normal value } 0.16-0.38 \text {. }\end{array}$} \\
\hline
\end{tabular}

\section{Lung imaging results}

CT abnormalities including ground-glass opacities, interstitial fibrosis, emphysema, bullae, and pleural thickening were observed in 14 SARS survivors, mostly $(12 / 14,85.6 \%)$ in the severe group. The most common abnormal lung radiologic findings were ground-glass opacities, detected in 8 (57.1\%) cases. Seven cases presented with interstitial fibrosis. Less common changes included emphysema, bullae, and pleural thickening, and none of the survivors showed pleural effusion. We compared longitudinal series of chest CT in some cases of the severe group, and the abnormalities remained relatively stable 1 year after the disease onset. Dynamic CT changes of a patient in the severe group were shown in Figure 4.

\section{Pulmonary function tests}

Pulmonary function tests including spirometry, lung volume and diffusion capacities proceeded in 52 subjects. One severe case had moderate impairment of FVC $(1 / 52,1.92 \%)$, and no one showed restrictive ventilatory dysfunction. The $\mathrm{FEF}_{25-75 \%}$ decreased in 19 patients (36.54\%) with the mean (SD) $75.93 \pm$ $21.57 \%$. Diffusion capacity was impaired in 19 patients (36.54\%), and the lowest was $62.2 \%$ of predicted values.

$\mathrm{FEV}_{1}, \mathrm{FEV}_{1} / \mathrm{FVC}$ and $\mathrm{FEF}_{25-75 \%}$ were lower in the severe group than that in the non-severe group ( $\mathrm{FEV}_{1} 2.48$ $\pm 0.514 \%$ vs $2.90 \pm 0.453 \mathrm{~L}, \mathrm{FEV}_{1} / \mathrm{FVC} 79.23 \pm 4.35 \%$ vs $82.64 \pm 4.80 \%, \mathrm{FEF}_{25-75 \%} 65.95 \pm 19.73 \%$ vs 
$82.69 \pm 20.36 \%, p=0.003,0.012$, and 0.005 , respectively). There was no statistically significant difference in lung diffusing capacity of carbon monoxide between the two groups ( $84.01 \pm 11.06 \% \mathrm{vs}$ $82.18 \pm 12.42 \%, p=0.576$ ). All the results of PFTs are provided in Table 2 .

\section{Discussion}

We investigated the current status of convalescent SARS patients to find out whether there is any longterm effect of SARS-CoV infection. In our study, most cases have continued to normal operation as expected. The majority of PFT values, cellular and humoral immune parameters are within the normal range. However, cases in the severe group revealed poor lung function than cases in the non-severe group, including small airway function ( $\mathrm{FEF}_{25-75} \%$ ) and diffuse capacity ( $\mathrm{DL}(\mathrm{CO})$ ). Plus the persistent $\mathrm{CT}$ abnormalities, our study indicated that SARS-CoV can cause permanent damage to the lung, especially in critically ill patients. Besides, the high percent of Treg cells in peripheral blood and the durability of serum antibodies indicate a persistent immune memory to SARS-CoV in both T- and B- cells. However, whether it is a virus-specific protective immune response requires further exploration.

Our study found that the pulmonary functions of SARS survivors largely returned to normal after 15 years of convalescence, most of them (81.03\%) were still full-time employed, and $69.6 \%$ had an mMRC scale score of $0-1$. The lung function damage was characterized by small airway abnormalities (36.5\%) and reduced diffusion capacity (36.5\%). Previous studies evaluating the lung function status $[8,9]$ in SARS survivors observed consistent results with our study. The impairment of $\mathrm{DL}(\mathrm{CO})$ was significant in all studies, which suggests impairment in the intra-alveolar diffusion pathway. Airway obstruction and small airway dysfunction were less common in the studies. In our study, small airway dysfunction was as common as damaged diffusion capacity. Survivors from severe COVID-19 also revealed small airway dysfunction $[10,11]$. As previously reported, the predominant pathological finding in SARS was diffuse alveolar damage in the early phase of the disease [12] but in the later course of the disease, dense septal and alveolar fibrosis were seen [13]. Recently report demonstrated that the COVID-19 virus particles could be observed in distal airway mucosal epithelial through electron microscopy [14]. Therefore, bronchiolitis may exist and result in dysfunction of the small airway.

No statistical differences in the pulmonary function measurements were observed in the longitudinal studies [8,9], as compared with those measured either immediately after recovery or after 24 months post-illness. These results are in accord with our study, which showed persistent CT abnormalities in SARS convalescent patients. Besides, we previously reported that the CT abnormalities remained stable after 24 months post-infection [15]. These data suggested permanent lung damage due to coronavirus and indicated the necessity of early respiratory rehabilitation training.

We also found that approximately $20 \%$ of SARS convalescent patients still have a detectable level of serum IgG specific to SARS-CoV, with $20.69 \%$ positive to S-RBD protein and $18.97 \%$ positive to N protein, which was not related to the disease severity. These findings are somewhat surprising given the fact that other researches have shown that SARS-CoV-specific antibodies waned over time [16] and SARS-CoV- 
specific IgG antibodies could not be detected in more than $90 \%$ of patients six years after infection [17]. The researchers have reported long-lived SARS-CoV-specific memory T cells but not B cells in SARS survivors. SARS-CoV-1 reactive CD4+ T cells could be detected even 17 years after infection [18]. Our data indicated the existence of virus-specific memory B cells in the peripheral blood, which could still be activated to secret IgG up to 15 years post-infection. An improved detection threshold might explain the different results. Further evidence is required to validate whether the antibodies can confer protection against SARS-CoV-1, or even better, cross-protection against COVID-19.

Besides, we observed a slight elevation of Treg cells in peripheral blood in SARS survivors after 15 years, as compared with healthy controls ( $3.85 \pm 1.31 \%$ vs $3.34 \pm 0.97 \%)$. The values were still within the normal range and no clinical features were observed to be related to the higher proportion of Treg cells, including the disease severity. However, the autoimmune characteristics have been observed in critical COVID-19 cases [19], and autoimmune and inflammatory diseases were observed following COVID-19 as well [20]. It is well known that Treg-mediated active maintenance of self-tolerance is the pathogenetic mechanism of autoimmune diseases [21]. Although the connections between SARS and autoimmune or inflammatory diseases were not reported, the cross-reaction of SARS-CoV antigen with autoantibodies had already been observed as early as 2004 [22]. In addition to this, Treg cells can also limit pulmonary immunopathology in respiratory virus infections [23]. And in West Nile infection, Tregs can protect from central nervous system immunopathology by controlling CD8 T-cell responses [24]. The exact role of Treg cell reaction to coronavirus infection might need to be further explored.

There are several limitations to this study. First, although this study had the largest sample size for an evaluation of the long-term effects of SARS, We failed to make serial assessments over 15 years. This limitation means that study findings need to be interpreted cautiously. Further comparisons over time would be required to verify the observations. Second, although full lung function tests were conducted in our study, we did not perform 6MWT or cardiopulmonary exercise testing to verify their exercise capacities, as a great part of our cases were complaining of fatigue when questioned. The results might therefore not be representative of the entire cohort, especially those with normal $\mathrm{DL}(\mathrm{CO})$. Additional factors such as muscle deconditioning and steroid myopathy should be considered in further studies.

\section{Conclusions}

In summary, more than $30 \%$ of SARS survivors had impaired DL(CO) and over $30 \%$ of them had small airway dysfunction 15 years after SARS onset. CT abnormalities remained in over $20 \%$ of SARS subjects. SARS can lead to persistent lung abnormalities in survivors. Health authorities should provide more support for early pulmonary rehabilitation. The long-lived immune memory response requires further research to assess the potential beneficial immunity against coronavirus.

\section{List Of Abbreviations}




\begin{tabular}{|ll|}
\hline Abbreviations & Complete name \\
\hline ACE2 & Angiotensin converting enzyme 2 \\
\hline CoV & Coronavirus \\
\hline DIC & disseminated intravascular coagulation \\
\hline DLCO & Diffusion Capacity for Carbon Monoxide of the Lung \\
\hline ELISA & Diffusion Capacity for Carbon Monoxide of the Lung/Alveolar volume \\
\hline FEF $25-75 \%$ & forced expiratory flow between 25 and $75 \%$ of forced vital capacity \\
\hline FEV 1 & forced expiratory volume in one second \\
\hline FEV ${ }_{1} /$ FVC\% & forced expiratory volume in one second/Forced vital capacity \\
\hline FVC & Forced vital capacity \\
\hline GGO & Ground-Glass opacity \\
\hline HCWs & health care workers \\
\hline HRCT & high resolution computerized tomography \\
\hline HRQoL & Health-related quality of life \\
\hline RT-PCR & reverse transcription polymerase chain reaction \\
\hline RT-PCR & Real-time PCR \\
\hline RV & residual volume \\
\hline SARS & severe acute respiratory syndrome \\
\hline TLC & World Health Organization \\
\hline WHO & \\
\hline
\end{tabular}

\section{Declarations}

Ethics approval and consent to participate: The study was approved by the ethics committee of Beijing University People's Hospital (PHB0102018-01). The written informed consent was obtained from all participants.

Consent for publication: Not applicable.

Availability of data and materials: The datasets used and/or analysed during the current study are available from the corresponding author on reasonable request. 
Competing interests: The authors declare that there is no conflict of interest.

Funding: The work was funded by grants from the National Key Research and Development Program "Precision Medicine Research" from the Ministry of Science and Technology of China (2016YFC0903800), the Emergency Scientific Research Project of Novel Coronavirus Prevention and Control from Xiamen University (20720200017, 20720200032).

Authors' contributions: ZG had the idea for and designed the study and had full access to all data in the study and take responsibility for the integrity of the data and the accuracy of the data analysis. $\mathrm{JL}$ and YZ contributed equally to the drafting of the manuscript. ZG, JL and $Y Z$ contributed to critical revision of the manuscript for important intellectual content. JL and $Y Z$ contributed to the statistical analysis. JL, ZY, $Z Y, F P, B Y$ and $Y C$ contributed to the data acquisition. $Y Z, Y C, G Z$ and $Y Z$ contributed to the SARS-CoV specific antibodies detection. JL, YZ and LZ contributed to the $T$ lymphocyte subsets analysis. JL, YZ, BY, $Y C, F P, L Z, Y Z$ and $Z G$ contributed to data analysis or data interpretation. The final version had been reviewed and approved by all authors.

Acknowledgements: The authors would like to thank the following colleagues who have offered tremendous help in this study: Yan Yu and Yu Xie.

\section{References}

1. Lee N, Hui D, Wu A, Chan P, Cameron P, Joynt GM, Ahuja A, Yung MY, Leung CB, To KF et al: A major outbreak of severe acute respiratory syndrome in Hong Kong. N Engl J Med 2003, 348(20):19861994.

2. Tsang KW, Ho PL, Ooi GC, Yee WK, Wang T, Chan-Yeung M, Lam WK, Seto WH, Yam LY, Cheung TM et al: A cluster of cases of severe acute respiratory syndrome in Hong Kong. N Engl J Med 2003, 348(20):1977-1985.

3. WHO: http://www.who.int/csr/sars/country/2003_08_15/en/.

4. Sohrabi C, Alsafi Z, O'Neill N, Khan M, Kerwan A, Al-Jabir A, losifidis C, Agha R: World Health Organization declares global emergency: A review of the 2019 novel coronavirus (COVID-19). Int J Surg 2020, 76:71-76.

5. Gómez-Ochoa SA, Franco OH, Rojas LZ, Raguindin PF, Roa-Díaz ZM, Wyssmann BM, Guevara SLR, Echeverría LE, Glisic M, Muka T: COVID-19 in health-care workers: a living systematic review and meta-analysis of prevalence, risk factors, clinical characteristics, and outcomes. American journal of epidemiology 2021, 190(1):161-175.

6. Wen Z, Lu J, Li J, Li N, Zhao J, Wang J, Yu L, Yang W: Determining the filtration efficiency of half-face medical protection mask (N99) against viral aerosol. Aerobiologia 2010, 26(3):245-251.

7. Yang Y, Peng F, Wang R, Yange M, Guan K, Jiang T, Xu G, Sun J, Chang C: The deadly coronaviruses: The 2003 SARS pandemic and the 2020 novel coronavirus epidemic in China. J Autoimmun 2020, 109:102434. 
8. Li L, Sun X, Wu Q, Wu Q, Xing Z, Yu H: [The lung function status in patients with severe acute respiratory syndrome after ten years of convalescence in Tianjin]. Zhonghua jie he he hu xi za zhi= Zhonghua jiehe he huxi zazhi = Chinese journal of tuberculosis and respiratory diseases 2015, 38(8):575-578.

9. Ngai JC, Ko FW, Ng SS, To KW, Tong M, Hui DS: The long-term impact of severe acute respiratory syndrome on pulmonary function, exercise capacity and health status. Respirology (Carlton, Vic) 2010, 15(3):543-550.

10. You J, Zhang L, Ni-Jia-Ti M-Y-d-L, Zhang J, Hu F, Chen L, Dong Y, Yang K, Zhang B, Zhang S: Anormal pulmonary function and residual CT abnormalities in rehabilitating COVID-19 patients after discharge. The Journal of infection 2020, 81(2):e150-e152.

11. Li X, Wang $C$, Kou S, Luo P, Zhao M, Yu K: Lung ventilation function characteristics of survivors from severe COVID-19: a prospective study. Critical Care 2020, 24(1):300.

12. Lam C, Lauder I, Lam T, Gandek B: Population based norming of the Chinese (HK) version of the SF36 health survey. Hong Kong Practitioner 1999.

13. Gu J, Korteweg C: Pathology and pathogenesis of severe acute respiratory syndrome. The American journal of pathology 2007, 170(4):1136-1147.

14. Yao X, Li T, He Z, Ping Y, Liu H, Yu S, Mou H, Wang L, Zhang H, Fu W: A pathological report of three COVID-19 cases by minimally invasive autopsies. Zhonghua bing li xue za zhi=Chinese journal of pathology 2020, 49:E009-E009.

15. Zhang P, Li J, Liu H, Han N, Ju J, Kou Y, Chen L, Jiang M, Pan F, Zheng Y: Long-term bone and lung consequences associated with hospital-acquired severe acute respiratory syndrome: a 15-year follow-up from a prospective cohort study. Bone research 2020, 8(1):1-8.

16. Xie L, Liu Y, Xiao Y, Tian Q, Fan B, Zhao H, Chen W: Follow-up Study on Pulmonary Function and Lung Radiographic Changes in Rehabilitating Severe Acute Respiratory Syndrome Patients After Discharge. Chest 2005, 127(6):2119-2124.

17. Tang F, Quan Y, Xin ZT, Wrammert J, Ma MJ, Lv H, Wang TB, Yang H, Richardus JH, Liu W et al: Lack of peripheral memory $B$ cell responses in recovered patients with severe acute respiratory syndrome: a six-year follow-up study. J Immunol 2011, 186(12):7264-7268.

18. Swadling L, Maini MK: T cells in COVID-19-united in diversity. Nature immunology 2020, 21(11):1307-1308.

19. Zhou Y, Han T, Chen J, Hou C, Hua L, He S, Guo Y, Zhang S, Wang Y, Yuan J: Clinical and autoimmune characteristics of severe and critical cases of COVID-19. Clinical and translational science 2020, 13(6):1077-1086.

20. Galeotti C, Bayry J: Autoimmune and inflammatory diseases following COVID-19. Nature Reviews Rheumatology 2020, 16(8):413-414.

21. Sakaguchi S, Sakaguchi N: Regulatory T cells in immunologic self-tolerance and autoimmune disease. International reviews of immunology 2005, 24(3-4):211-226. 
22. Wang Y, Sun S, Shen H, Jiang L, Zhang M, Xiao D, Liu Y, Ma X, Zhang Y, Guo N et al: Cross-reaction of SARS-CoV antigen with autoantibodies in autoimmune diseases. Cellular \& molecular immunology 2004, 1(4):304-307.

23. Loebbermann J, Durant L, Thornton H, Johansson C, Openshaw PJ: Defective immunoregulation in RSV vaccine-augmented viral lung disease restored by selective chemoattraction of regulatory $\mathrm{T}$ cells. Proceedings of the National Academy of Sciences 2013, 110(8):2987-2992.

24. Lanteri MC, O’Brien KM, Purtha WE, Cameron MJ, Lund JM, Owen RE, Heitman JW, Custer B, Hirschkorn DF, Tobler LH: Tregs control the development of symptomatic West Nile virus infection in humans and mice. The Journal of clinical investigation 2009, 119(11):3266-3277.

\section{Figures}
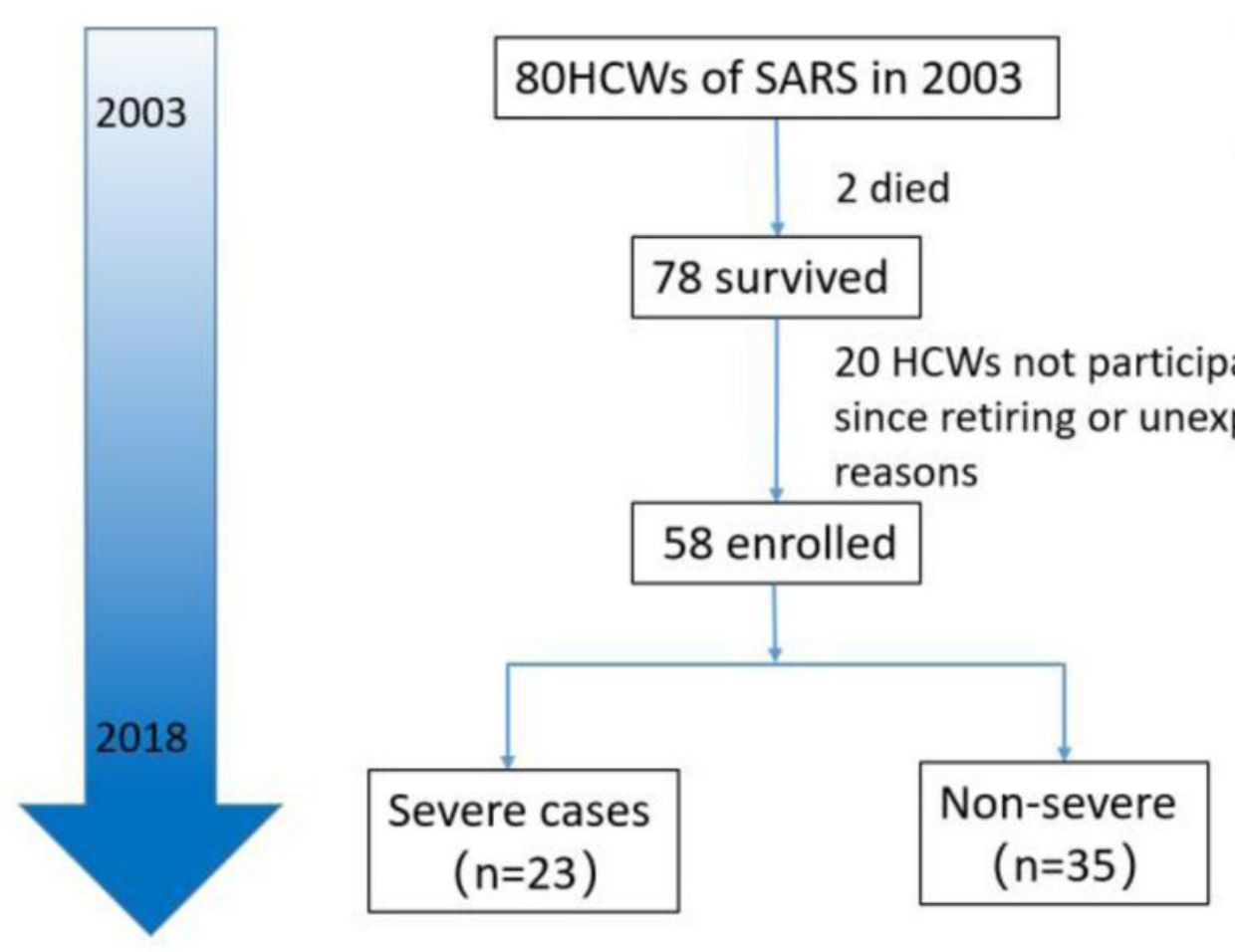

co-workers of SARS patients $(n=57)$

\section{Figure 1}

Flow diagram for study participants 

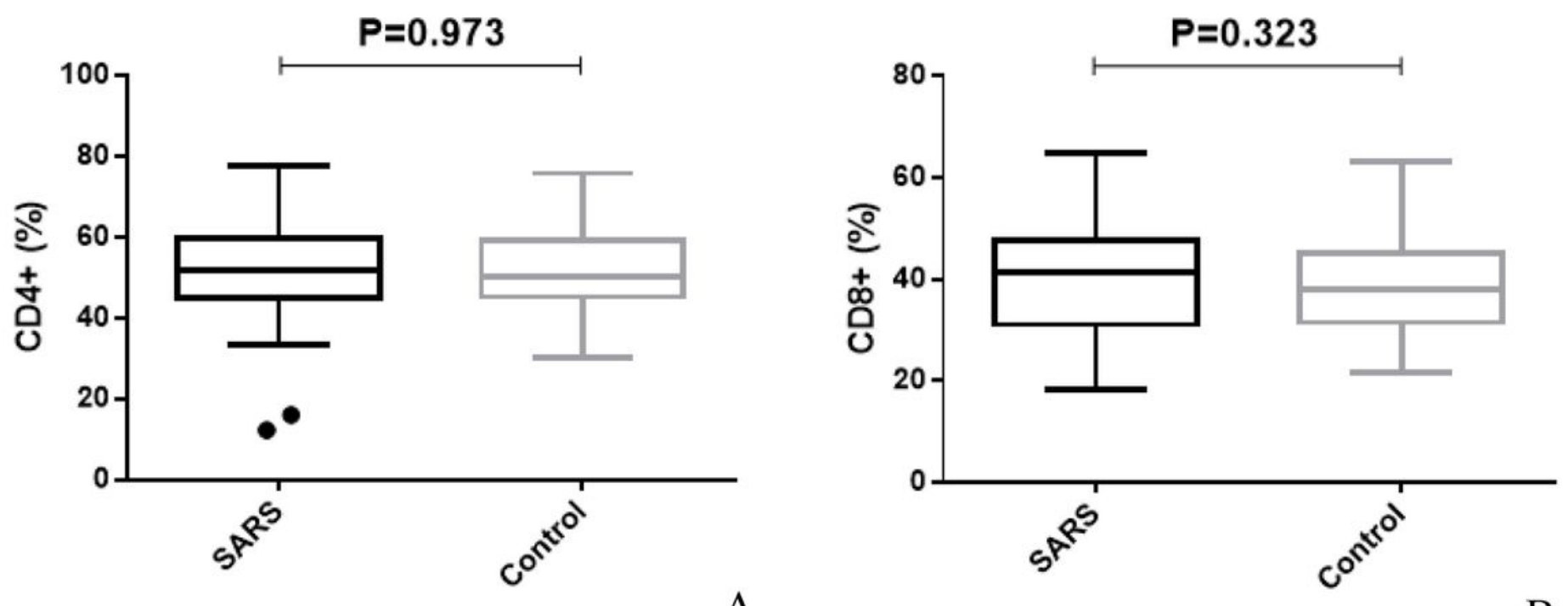

A
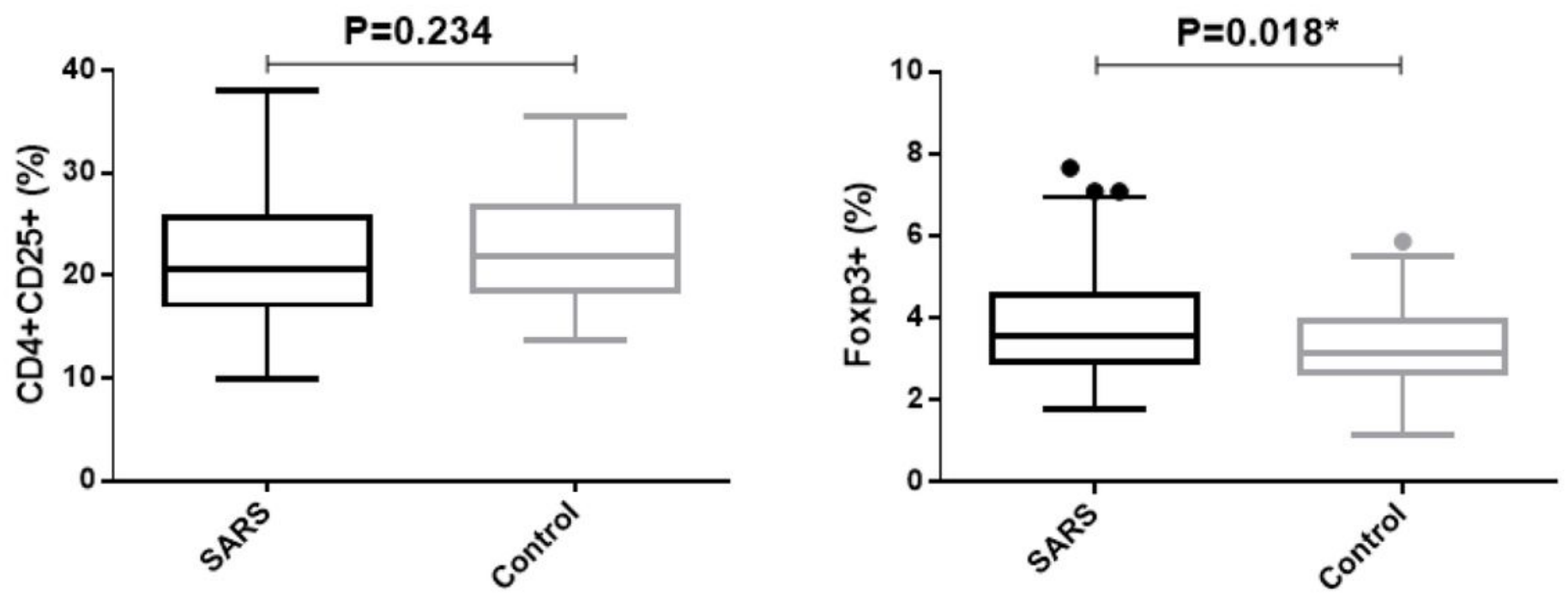

$\mathrm{C}$

$\mathrm{D}$

Figure 2

Peripheral T cell subsets between SARS survivors and healthy controls The proportion of CD4+ (panel A), CD8+ (panel B), CD4+CD25+ (panel C) and CD4+CD25+Foxp3+ regulatory T cells (panel D) between SARS survivors and healthy controls. 
A

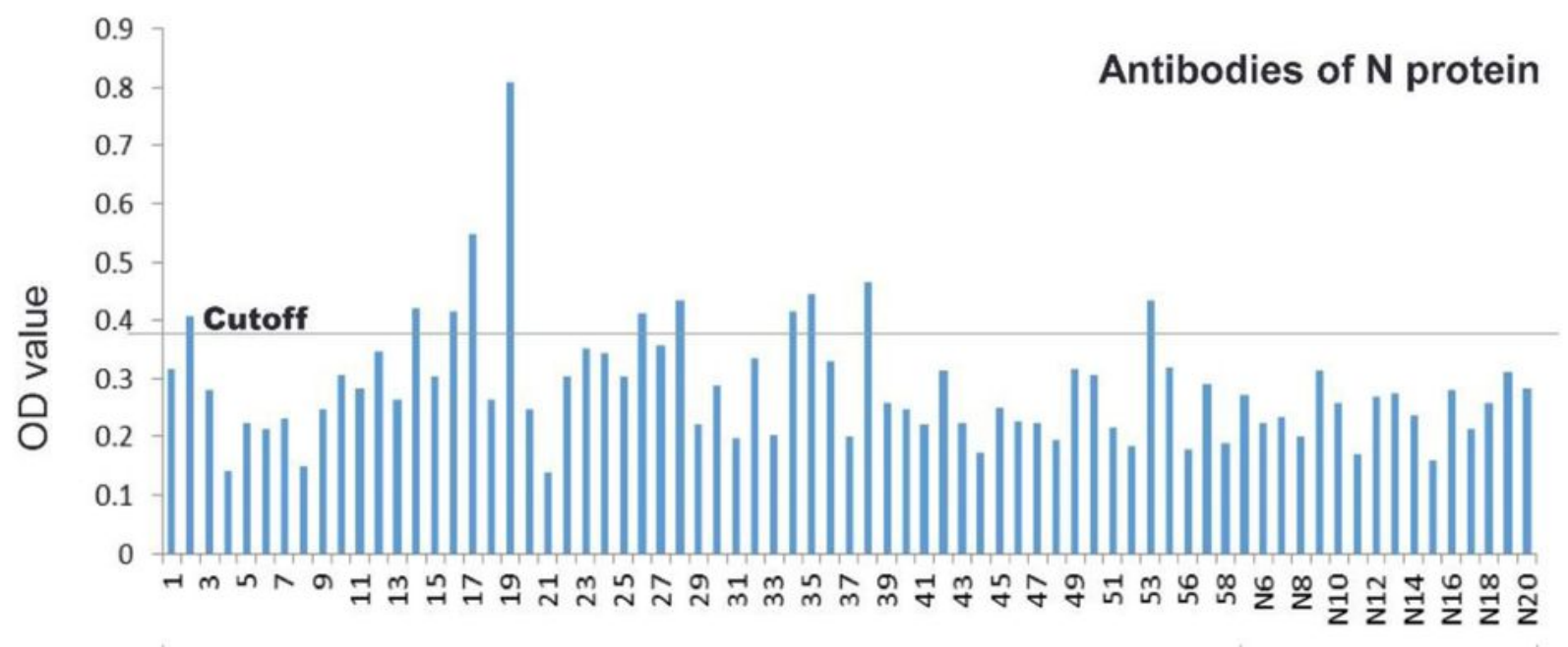

SARS

Control

B

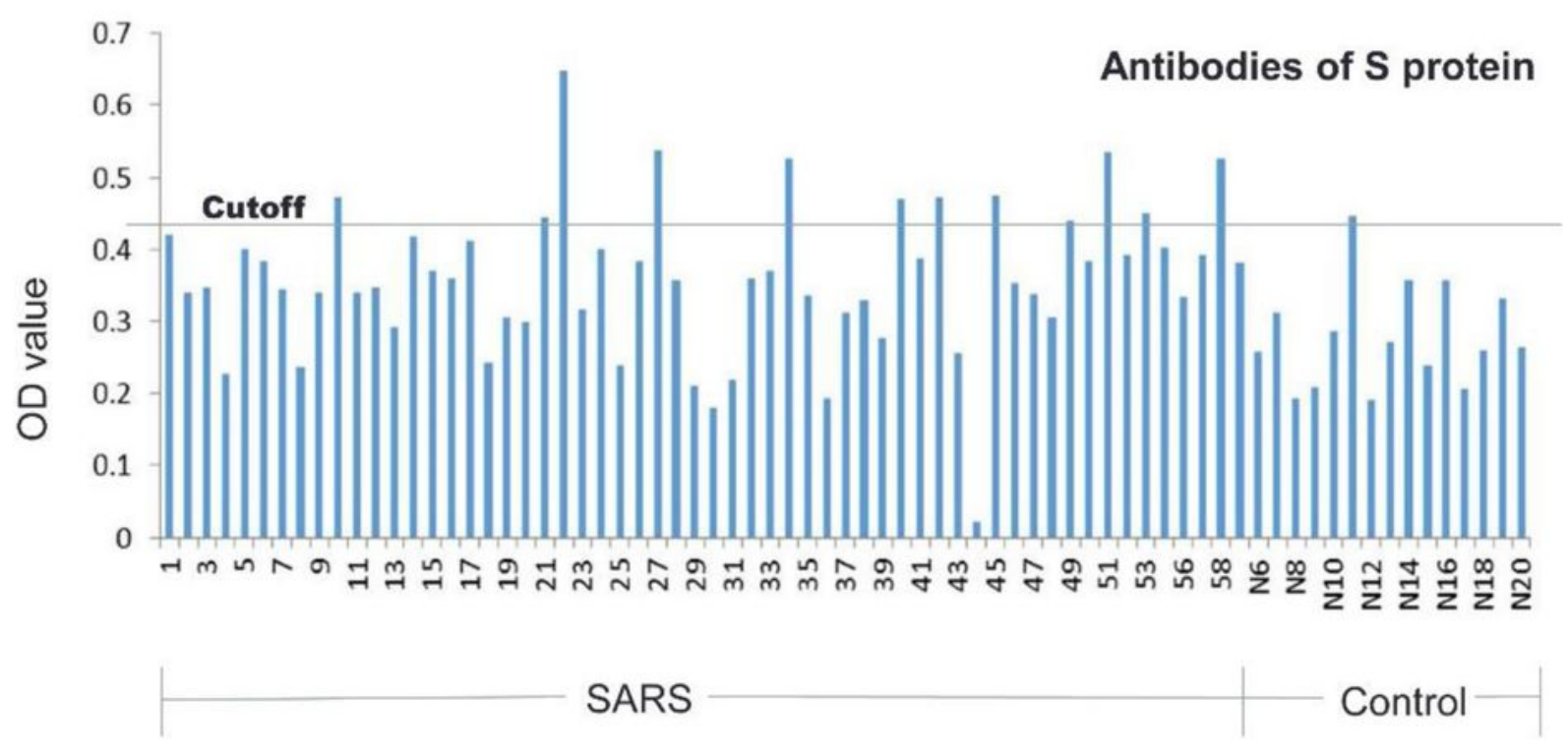

Figure 3

SARS-CoV specific IgG antibodies in serum after 15 years of infection ELISA results of Specific IgG antibody against SARS N protein (panel A) and against S-RBD protein (panel B). (S-RBD: receptor binding domain of spike protein; $\mathrm{N}$ protein: nuclear protein.) 

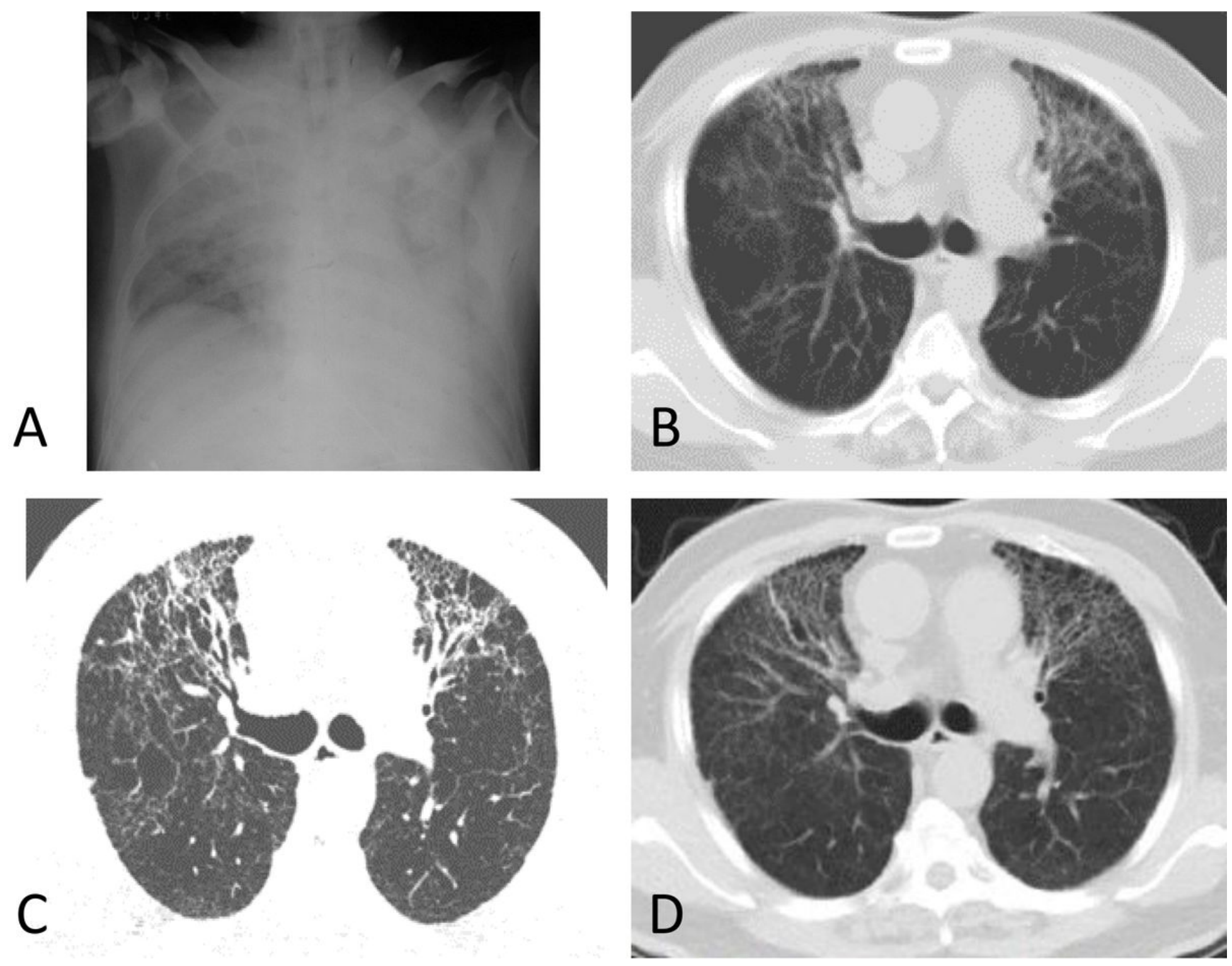

Figure 4

Serial CT images of a male SARS survivor in 15 years Panel A showed diffused consolidation in bilateral lungs on June 14, 2003. Panel B-D showed a stable reticular interstitial fibrosis with tractive bronchiectasis in the serial follow-up, after 1 year (panel B, November 2004), 3 years (panel C, August 2006) and 15 years (panel D, March 2018) of SARS pneumonia. 